\title{
CINTA: Solusi Epistemologis Kerukunan Beragama (Kajian Titik Temu Antara Filsafat Perenial dan Tasawuf)
}

\author{
Cucu Setiawan \\ UIN Sunan Gunung Djati Bandung \\ Email: cucu.setiawan@uinsgd.ac.id
}

\begin{abstract}
Today, the interfaith conflicts still occur frequently. This makes us aware of the importance of involving religion to take part in paying attention to these humanitarian problems and trying to solve them together. Involving religion in this case is clear as a proof that religion can be a way out of every problem, since religion is not enough when it is only as a forum to manifest our longing to God. Religion demands a concrete involvement in all ethical problems of humanity. This present study uses a qualitative method of literature review. This paper aims to deepen the study of the religious recognition of love by using Perennial Philosophy and Sufism to make it becomes the epistemological foundation of religious harmony. The result of this study concludes that love, which is the essence of every religion, is a logical and ethical choice in the effort to include religion in the above problem. Religious recognition of love becomes an epistemological solution to the realization of religious harmony. Love has removed the attributes of formality. Love is no longer looking at position, religion, and even at the human's role and status. By considering love as the essence, people only consider that I am human, you are human, and we are all human. So, when all realize that they are human beings who live because of love, human's duty is only to love one another.
\end{abstract}

Keywords:

Love, Perennial Philosophy, Religious Harmony, and Sufism

\begin{abstract}
Abstrak
Dewasa ini konflik lintas agama masih kerap terjadi. Hal itu semakin menyadarkan kita akan pentingnya melibatkan agama untuk ikut andil dalam memperhatikan problem kemanusiaan tersebut dan berupaya menyelesaikannya secara bersama-sama. Melibatkan agama dalam hal seperti ini jelas sebagai bukti bahwa agama dapat menjadi jalan keluar dari setiap permasalahan, sebab agama tidak cukup manakala hanya sebagai wadah untuk mengejawantahkan kerinduan pada Tuhan, ia menuntut keterlibatan konkrit dalam seluruh problem etis umat manusia. Penelitian ini menggunakan metode kualitatif pengkajian Pustaka. Karya tulis ini bertujuan untuk memperdalam tentang kajian pengakuan agama agama tentang cinta yang menggunakan analisis filsafat perennial dan tasawuf dan menjadi pijakan epistemologis kerukunan beragama. Penulis berkesimpulan : Cinta yang menjadi inti sari setiap agama adalah pilihan logis dan etis dalam upaya mengikutsertakan agama pada persoalan di atas. Pengakuan agama agama tentang cinta menjadi solusi epistemologis terwujudnya kerukunan umat beragama. Cinta telah menghapus atributatribut yang bersifat formalitas. Cinta tidak lagi memandang apa jabatan, apa agama, bahkan sampai pada apa status dan peran manusia. Yang ada dalam pikiran manusia adalah: aku manusia, engkau manusia, kita semua manusia. Maka ketika semuanya menyadari bahwa kita adalah manusia yang hidup karena cinta, tugas kita adalah saling mencintai.
\end{abstract}

Keywords:

Cinta, Filsafat Perenial, Kerukunan beragama, dan Tasawuf

DOI: http://dx.doi.org/10.15575/saq.v4i2.7721

Received: 2020-01-27; Accepted: 2020-01-27 ; Published: 2020-01-29 


\section{A. PENDAHULUAN}

Pada permulaan tahun 1960-1998 di beberapa wilayah Indonesia ramai dengan beragam persoalan sosial terutama persoalan

yang bersinggungan dengan SARA (Suku, Agama, Ras, dan Antargolongan). Pada masa itu, meskipun isu konflik etnis juga meningkat, peristiwa yang paling banyak terjadi adalah konflik yang bernuansa agama, di antaranya seperti kasus perang ideologi antara pemeluk agama Islam dengan agama Kristen, yang menurut catatan sejarah, penganut agama Kristen melakukan upaya kristenisasi yang berlebihan dengan cara pemberian uang dan pembangunan gereja di tengah mayoritas umat muslim.

Pada waktu yang lain, perseteruan yang menyangkut agama pun juga muncul setelahnya yaitu ketika maraknya truth claim (klaim kebenaran) yang muncul dari masingmasing agama. $^{2}$ Pertama, di satu sisi agama Islam mengakui dan menyadari bahwa agamanya-lah yang paling benar sedangkan agama lain salah dengan mengungkapkan beberapa alasan serta dalil naqli yang merujuk kepada al-Quran dan Hadis Rasul Saw. Alasan yang menjadi dasar epistemologis pemikiran kaum muslim tersebut tertuang dalam alQuran surah, al-Imran: 19, "Sesungguhnya agama di sisi Allah adalah Islam". Ayat ini menjadi salah satu ayat yang populer bagi sebagian kaum muslim pejuang eksistensi agama tunggal (Islam) sebagai agama terakhir dan terpercaya. Melihat ini, Rasyid Ridha memberikan penjelasan yang jelih, menurutnya, bahwa kata "agama sejati" adalah Islam, atau kepasrahan terhadap Tuhan, dan tidak secara khusus mengacu pada agama yang secara resmi disebut Islam. Sebab Ibrahim pun menyatakan dirinya sebagai seorang muslim, hamba yang tunduk dan pasrah kepada Tuhan.

\footnotetext{
${ }^{1}$ Amos Sukamto, "Ketegangan Antar Kelompok Agama Pada Masa Orde Lama Sampai Awal Orde Baru: Dari Perumusan Ideologi Negara Sampai Konflik Fisik”, Teologi Indonesia, Juli 2013, hlm.41.

${ }^{2}$ Pada dasarnya kasus ini juga terjadi bersamaan dengan perang ideologi antar agama tersebut. Namun hal itu lebih kental terjadi di beberapa waktu setelahnya.
}

Oleh karena itu, makna yang sebenarnya dari kata "sejati" adalah orang yang senantiasa memiliki iman dan mewujudkannya dalam bentuk perilaku yang soleh, apa pun konteksnya. $^{3}$ Namun, meskipun masih mengandung multitafsir, mereka tetap meyakini bahwa ayat ini merupakan pijakan kuat untuk meyakini tidak ada agama lain yang benar setelah turunnya agama Islam yang dibawa langsung oleh Nabi Muhammad.

Terlepas dari penafsiran, mereka juga memberikan ulasan yang lebih matang dengan menggunakan beberapa ayat al-Quran lainnya, seperti yang termaktub dalam surah al-Imran ayat 85 , "dan barangsiapa mencari agama selain Islam, dia tidak akan diterima, dan diakhirat dia termasuk orang yang rugi". Ayat ini juga termasuk ayat yang mashur di kalangan mereka sehingga ayat ini dijadikan sebagai pembenaran bahwa agama Islam adalah agama yang benar dan selainnya salah. Dan bahkan untuk lebih mempertegas keyakinan mereka, mereka menggunakan ayat tentang kekafiran sebagai bentuk legalitas bahwa agama selain Islam adalah kafir.

Kedua, hal serupa juga terjadi pada agama lain, seperti Kristen. Dalam keyakinan Kristen bahwa keselamatan hanya ada pada Yesus dan tidak ada pada agama lain. Ini menandakan bahwa hanya yang berkeyakinan pada agama Kristenlah yang akan mendapatkan keselamatan pada saat dunia dan alam semesta hancur. Perdebatan yang sama juga terjadi antara agama Yahudi dengan agama Kristen yang saat itu terkenal dengan istilah "supersesi". Supersesi ini menurut orang Kristen, bahwa kami orang Kristen telah menggantikan kalian orang Yahudi sebagai umat pilihan Allah. Karena kalian tidak mengakui Yesus sebagai mesias dan membuatnya disalibkan, Allah telah menolak kalian dan memilih kami untuk menggantikan kalian. $^{4}$

\footnotetext{
${ }^{3}$ Mohammad Hasan Khalil, Islam dan Keselamatan Pemeluk Agama Lain, terj. Chandra Utama (Bandung: Mizan, 2016), hlm. 201.

${ }^{4}$ John L. Espasito, Darrel J. Fashing, Todd Lewis, World Religions Today: Agama Agama Dunia Dewasa
} 
Setelah jauh bertahun-tahun konflik ideologis, pada tahun berikutnya, pergesekan antar ideologi agama semakin memuncak sehingga tidak lagi sebatas pergesekan pada nalar keyakinan atau nalar doktrinasi, melainkan sudah masuk pada ranah aksi bela agama. Masing-masing melakukan pembelaan terhadap agamanya sendiri sehigga seringkali aksi bela agama yang dilakukan bertendensi pada anti-moral dan anti-sosial, hal itu terlihat maraknya kasus bom bunuh diri beberapa saat lalu yang dilakukan oleh beberapa penganut agama atas dasar emosional agama.

Beberapa kumpulan peristiwa di atas memberikan penjelasan bahwa kehidupan beragama tidak semudah seperti yang dibayangkan. Agama yang semulanya hanya dijadikan penuntun manusia untuk mengenali Tuhannya, kini agama malah dijadikan sebagai media untuk kekuasan. Agama satu ingin menguasai agama lain, sedangkan agama yang lain pun demikian, tidak mau kalah atas pergerakan agama lain meskipun menjadi mayoritas. Ketidaksaling mengakui terjadi antar agama, memberikan arti bahwa pluralisme bukan merupakan cita-cita yang diharapkan, melainkan menjadi musuh oleh sebagian mereka yang suka menjadikan agama sebagai kekuasaan. Padahal, menurut Faisal Ismail, dalam bukunya Islam, Doktrin, dan Isu-Isu Kontemporer menuturkan bawha pluralisme agama merupakan sebuah keniscayaan yang tidak ada kesalahan di dalamnya. Sebab Allah telah menjelaskan di dalam al-Quran bahwa Allah menciptakan keberagaman. Karena itu, menurut Faisal Ismail, pluralisme agama hendaknya diterima sebagai realitas duniawi atau keniscayaan yang mesti ada dalam kehidupan manusia. ${ }^{5}$

Melihat begitu peliknya permasalahan antarlintas agama, para sarjana muslim mencoba menganalisis akar masalah yang paling fundamental dari konflik yang terjadi antar agama ini. Salah satunya adalah Haidar

Ini, (Jakarta: PT Elex Media Komputindo, 2015), hlm. 178.

${ }^{5}$ Faisal Ismail, Islam, Doktrin, dan Isu-Isu

Kontemporer, (Yogyakarta: IRCiSoD, 2016), hlm.59.
Bagir, dalam bukunya yang fenomenal "Islam Tuhan Islam Manusia", bagir menuturkan bahwa terjadinya konflik antar agama dikarenakan minimnya spiritiualitas keagamaan yang padahal merupakan hal yang subtansial dari setiap agama itu sendiri. ${ }^{6}$ Perhatian bagir ini menunjukkan bahwa begitu banyak umat beragama yang hanya terjebak pada ketampanan ritual formalistik agama, memperindah tampilan luar akan tetapi kesemuanya itu tidak terakumulasi pada sikap perbuatan sehari-hari terhadap sosial sekitarnya. Padahal seharusnya, dalam istilah Gus Dur, seberapa pun kuatnya keimanan dan ketaatan kepada syariat mesti berwujud kecintaan kepada sesame manusia. ${ }^{7}$

Sarjana yang lain juga mengambil alih dalam menafsirkan apa yang mendasari terjadinya konflik sosial yang bernuansa agama tersebut, di antaranya Budhy Munawwar Rachman. Dalam salah satu ceramahnya Budhy mengatakan bahwa terjadinya konflik antaragama atau munculnya intoleransi beragama didasari pada minimnya pergaulan antar sesama pemeluk agama, sehingga pada suatu waktu perjumpaannya terhadap penganut agama lain membuat orang tersebut merasa shock atau kaget dan yang muncul adalah menarik diri untuk tidak berkompromi atau berinteraksi. ${ }^{8}$

Bertolak dari dua pendapat di atas, penulis mengutip pendapat dalam sudut pandang teori filsafat perennial dan tasawuf, bahwa munculnya konflik agama terjadi dikarenakan adanya kesenjangan antara unsur eksoterisme dan esoterisme agama, yang seharusnya kedua aspek tersebut merupakan dualitas integral yang saling berhubungan, antara satu dengan yang lain tidak bisa saling melepaskan dan

\footnotetext{
${ }^{6}$ Haidar Bagir, Islam Tuhan Islam Manusia, (Bandung: Mizan, 2017), hlm. 229

${ }^{7}$ Abdurrahman Wahid, "Primbumisasi Islam dalam Pergulatan Negara, Agama, dan Kebudayaan, (Depok: Desantara,2001), hlm.188.

${ }^{8}$ Salah satu ceramah Budhy saat mengisi acara diskusi halaqoh damai yang dihadiri oleh beberapa penganut agama di Bandung, Jawa Barat Desember 2018.
} 
melupakan. ${ }^{9}$ Kemudian, rasa cinta yang pada dasarnya merupakan bagian dari puncak perjalanan agama menjadi hal yang dikesampingkan atau menjadi aspek yang tidak terlalu penting dalam beragama sehingga juga menjadi pemicu munculnya konflik sosial yang bernuansa agama ini.

Melihat kondisi seperti ini, pada suatu waktu benar apa yang dikatakan oleh Charles Kimbal dalam bukunya Kala Agama Jadi Bencana. Buku ini merincikan bahwa kehidupan beragama tidak lagi sesuai dengan role dan core nya, sebab pertikaian serta konflik yang mengatasnamakan agama semakin marak terjadi. Buku ini secara tidak langsung dikritik oleh Karen Amstrong dalam bukunya Compassion, Amstrong mengatakan bahwa agama tidak ada hubungan dan tidak mungkin menjadi penyebab kekacauan umat beragama, sebab sejatinya agama adalah menyelamatkan manusia dari marabahaya. ${ }^{10}$ Meskipun Amstrong berpendirian demikian, fakta telah menunjukan bahwa beberapa konflik yang bernuansa keagamaan selalu dimotifasi oleh agama.

Merujuk pada pendapat di atas bahwa secara keseluruhan konflik atau kekerasan yang mengatasnamakan agama hanya terbatas pada aspek yang lahiriah saja, hanya sebatas pada perbedaan syariat atau cara beragama dan tidak menyentuh pada aspek yang inti yaitu menuju Tuhan yang satu, sehingga dengan dasar ini penulis tertarik untuk mengambil cinta yang merupakan titik temu antara filsafat perennial dan tasawuf menjadi pijakan epistemologis kerukunan umat beragama.

\section{B. HASIL DAN PEMBAHASAN \\ 1. Filsafat Perenial dan Tasawuf}

Dalam dunia keilmuan, dua diskursus ini (filsafat perennial dan tasawuf) merupakan dua bagian ilmu yang tidak bisa dilupakan

\footnotetext{
${ }^{9}$ Arqom Kuswanjono, Filsafat Perenial dan Rekonstruksi Pemahaman Keberagamaan, (Yogyakarta: Filsafaft UGM, 2006), hlm. 101.

${ }^{10}$ Karen Amstrong, Compassion: 12 Langkah Menuju Hidup Belas Kasih, terj. Yuliani Liputo, (Bandung: Mizan, 2013), hlm. 10.
}

pengaruhnya. Pertama, dalam khasanah ilmu filsafat sendiri, filsafat perennial adalah filsafat yang dapat menjelaskan segala kejadian yang bersifat hakiki menyangkut kearifan yang diperlukan dalam menjalankan hidup yang benar yang menjadi hakikat seluruh agama dan tradisi-tradisi besar spiritualitas manusia. ${ }^{11}$ Adapun hal yang menjadi keistimewaan filsafat perenial ini adalah kemampuannya dalam mengkompromikan antar aspek eksoterime (fisik) dan esoterisme (metafisik) yang dalam agama merupakan dua hal yang saling dibutuhkan.

Secara etimologi filsafat perenial diambil dari bahasa latin yaitu perennis, yang secara definitif bermakna kekal atau abadi. Dalam kamus Oxford, Perenial juga bermakna demikian yaitu continiuing for a long time, berlanjut dalam waktu yang panjang. Ini artinya filsafat perenial memiliki jangkauan yang luas dan menyeluruh. Dan bahkan menurut beberapa filsuf filsafat perennial ini disebut sebagai filsafat keabadian. Terlepas dari makna kekekalan yang multitafsir, barangkali apa yang disebut dengan abadi atau kekal ini sebatas pada akhir kehidupan manusia.

Bila ditinjau dari segi historisnya, kemunculan filsafat perennial atau munculnya istilah philosphia perennis (filsafat keabadian), menurut Said Husain Nasr, barangkali digunakan pertama kalinya di dunia Barat oleh seorang akademisi yaitu Augusitinus Steuchus dalam memberikan judul karyanya De Perenni Philosophia yang sempat diterbitkan pada abad ke-15 atau tahun 1540 lalu. Beberapa tahun setelahnya, lebih kurang tahun 1715, istilah filsafat perennial ini kemudian dikembangkan atau dipopulerkan oleh Leibnitz dalam sepucuk suratnya yang berisikan tentang pencarian jejak-jejak kebenaran di kalangan filosof kuno dan tentang pemisahan yang terang dari yang

\footnotetext{
${ }^{11}$ Arqom Kuswanjono, Filsafat Perenial dan Rekonstruksi Pemahaman Keberagamaan, (Yogyakarta: Filsafat UGM, 2006), hlm. 96.
} 
gelap. ${ }^{12}$ Namun meskipun Leibnitz berupaya untuk mempopulerkan jenis filsafat ini, kemasyhuran filsafat ini masih tetap tertutup atau terduksi oleh aliran filsafat keduniawian yang saat itu sedang hangat mempersoalkan tentang evolusi pemikiran dan kemajuan menuju kebenaran.

Seperti penulis katakan di atas bahwa keistimewaan filsafat perennial ini terletak pada kemampuannya dalam mengkompromikan beberapa keyakinan yang ada, hal itu terlihat dari konsep philosophia perennial yang menyatakan bahwa, pertama, adanya kebenaran mutlak yang mengatur seluruh rangkaian alam mikrokosmos dan makrokosmos yang semua agama atau keyakinan mengakui keberadaan alam mikrokosmos dan makrokosmos. Kedua, filsafat perennial menyatakan bahwa setiap agama memiliki satu bentuk dan satu substansi. Misalnya Islam, Islam merupakan agama yang memiliki satu bentuk dan satu substansi. Islam dapat menyebar ke seluruh dunia bagaikan kilat dengan intensitas cahaya yang cepat berkat substansinya, dan pada waktu-waktu tertentu penyebarannya terhenti dikarenakan bentuknya. Artinya, jika ditinjau dari batas wilayah, nilai substansi agama apa pun tidak akan memiliki batasan wilayah, sebab ia lahir dari yang Maha Mutlak. Sedang bentuk dari agama, selalu mengalami keterbatasan sehingga ia dikatakan relatif.

Dari konsep perenial inilah kemudian yang menyatukan paham bahwa setiap agama memiliki nilai kebenarannya masing-masing, memiliki unsur eksoterisme dan esoterismenya sendiri dan oleh sebab itu manusia dituntut untuk menjalankan segala bentuk ajaran yang dia anggap benar dalam keyakinannya. Agama satu, Kristen misalnya, tidak berhak menyatakan bahwa agamanya memiliki kebenaran mutlak sehingga meniadakan kebenaran agama lain yang muncul setelahnya. Begitupun dengan kemunculan Islam, Islam tidak berhak menafikan eksistensi

\footnotetext{
${ }^{12}$ Frithjof Schuon, Islam and the Perennial Philosophy,
} terj. Rahmani Astuti, (Bandung: Mizan, 1994), hlm. 7. agama terdahulu, meskipun dalam beberapa referensi dikatakan bahwa Islam adalah agama terakhir. Kedatangan Islam bukanlah bemaksud untuk mensupersesi keberadaan agama lain, melainkan Islam hadir memiliki konsep kebenarannya sendiri dan tidak melanggar keyakinan agama lain. Hal ini semakin meyakinakan bahwa konsep filsafat perennial merupakan bentuk paham yang mengantarkan ke jalan menjunjung tinggi nilai esoterisme agama. Nilai esoterisme tertinggi menurut philosphia perennial adalah cinta, yaitu salah satu bagian dari beragam sifat Tuhan yang fungsinya mengasihi seluruh makhluk yang ada di bawah-Nya.

Kedua, disiplin ilmu lainnya yaitu tasawuf. Tasawuf dalam wawasan keislaman merupakan ilmu yang menjadi inti dari ajaran Islam. Jika dalam agama Islam itu ada tiga tiang keislaman, Islam, Iman, dan Ihsan, maka Ihsan itulah yang menjadi puncak dari tasawuf. Seseorang yang ingin mencapai puncak keberagamaan tersebut harus melalui tiga tiang tersebut. Sehingga Imam al-Ghazali pernah berkata "berfiqh tanpa tasawuf maka fasiq, sedangkan bertasawuf tanpa berfiqh adalah zindiq".

Dalam catatan sejarahnya, tasawuf bukanlah sebuah nama, melainkan sebuah rutinitas keseharian Nabi dan Sahabat dalam menjalankan syariat Islam secara kaffah. Karena tidak adanya peng-istilahan tasawuf pada saat itu nama tasawuf tidak terkenal luas di kalangan masyarakat Arab. Kemunculan istilah tasawuf baru dikenal sejak setelah wafatnya Nabi Muhammad atau lebih kurang kemunculan isitlah tasawuf dan terkenalnya aliran ini di abad ke 2 hijriah. Namun meskipun nama tasawuf tidak ada pada zaman Rasul ataupun kurang dikenal, nilai-nilai tasawuf sudah ada pada zamannya dan para sahabat Rasul sangat gemar menjalani nilai substansial tersebut. Salah satu bagian dari nilai tasawuf yang dilakukan oleh para sahabat Rasul masa itu ialah kezuhudan. Ada beberapa alasan mengapa istilah tasawuf tidak terlalu begitu dikenal atau mengapa para sahabat yang taat menjalani syariat agama tidak disebut sebagai sufi: beberapa pendapat ulama 
mengatakan bahwa nama "sahabat" itu jauh lebih mulia dari pada peng-istilahan tasawuf itu sendiri

Tasawuf secara etimologi, pendapat yang paling populer dan mendekati kebenaran adalah shuf yang berarti bulu domba atau wol. ${ }^{13}$ Pendapat ini juga diyakini oleh salah seorang orientalis ${ }^{14}$ bahwa kata shuf atau bulu domba lebih mendekati kebenaran makna kata tasawuf. Sedangkan secara terminology atau secara istilah, pendefenisian tentang tasawuf jauh lebih banyak, beberapa pakar berupaya mendefinisikannya, di antaranya pendapat yang diutarakan oleh Imam Junaid alBaghdadi. Menurut beliau tasawuf merupakan upaya pembersihan hati dari apa yang mengganggu perasaan kebanyakan makhluk, memadamkan sifat-sifat kelemahan kita sebagai manusia, menjauhi segala seruan hawa nafsu, kemudian mendekati sifat-sifat kerohanian. ${ }^{15}$ Dari pendapat ini bisa kita lihat dan cermati bahwa manusia untuk mencapai puncak keberagamaan yang utuh dan sempurna manusia harus meninggalkan dirinya melalui pengosongan diri dari sifat ego. Ego, menurut syekh Junaid, adalah penghalang dari ketersambungan hamba dengan sang Khalik yang mengakibatkan sang hamba tidak mendapatkan pancaran ketuhanan.

Jika ditelaah lebih mendalam, pemahaman ini mengarahkan kepada sebuah sikap untuk lebih memperhatikan nilai yang substansial dari macam-macam syariat. Misalnya, sebuah syariat tidak hanya dibuat sebagai aturan kewajiban semata, melainkan ada unsur terdalam yang menjadi core atau inti dari

\footnotetext{
${ }^{13}$ Athoullah Ahmad, Diktat Ilmu Akhlak dan Ilmu Tasawuf, Serang: Fakultas Syariah IAIN Sunan Gunung Djati Bandung, 1985, hlm. 96

${ }^{14}$ J. Spencer Trmingham, seorang orientalis, berpendapat bahwa tasawuaf yang dalam bahasa orang Baraat disebut mysticism lebih tepat berasal dari kata Shuf yang berarti pakaian terbuat dari bulu domba (lihat J. Spencer Trimingham, the Sufi Oreders in Islam, London Oxford New York, Oxford University Press, 1973, hlm.1)

${ }^{15}$ Rosihon Anwar, Akhlak Tasawuf, (Bandung: Pustaka Setia, 2010), hlm. 147.
}

ibadah itu sendiri. Sehingga segala keberhasilan aktivitas ibadah syariat mestinya terwujud dalam bentuk perubuatan, seperti Tuhan yang dengan Maha Rahmatnya, dengan Maha Mahabbahnya Dia memberikan nikmat kepada semua manusia. Manusia pun demikian, segala aktivitas ibadah lahiriannya harus mampu mengantarkannya pada puncak agama itu sendiri, yaitu berdamai pada siapapun melalui cinta Allah.

\section{Cinta: Titik Temu Filsafat Perenial dan Tasawuf}

Dengan demikian, merujuk pada penjelasan umum dari kedua disiplin ilmu tersebut, ada dua hal titik kesamaan di dalamnya: esoterisme dan cinta. Pertama, di antara filsafat perennial dan tasawuf bagian yang paling penting adalah esoterisme. Perennial menjelaskan bahwa esoterisme agama merupakan dimensi yang terdalam atau terinti dari agama. Seorang yang ingin terjun kedalam lembah inti agama ia mesti menjalani proses atau maqomat tertentu yang dapat mengantarkannya pada puncak keberagamaan itu. Tasawuf juga mengatakan demikian sesuai dengan apa yang diaktakan oleh Imam Junaid al-Baghdadi di atas. Kedua, Selain dari esoterisme, filsafat perennial dan tasawuf juga memiliki kesamaan yaitu cinta. Cinta bagi kedua disiplin ilmu ini merupakan titik paling atas dalam sebuah pengalaman spiritual. Ketika seseorang mulai mencapai puncak spiritualitas tersebut, dia mulai mendapatkan percikan cinta Tuhan dalam dirinya sehingga yang muncul adalah sebuah sikap yang selalu memberikan ketentraman dan ketenangan kepada orang lain sama seperti sikap Tuhan kepada hamba-Nya, penuh Rahmat.

\section{Pengakuan Agama Agama Tentang Cinta}

Tidak satupun agama yang mengingkari keagungan cinta. Hal ini dikarenakan masingmasing agama mengakui bahwa cinta adalah benih dan puncak tertinggi kehidupan. Fritchof Schuon, seorang sufi asal Swiss, dalam bukunya "The Transendent Unity of 
Religion", ia mengatakan bahwa cinta adalah kehidupan. Sebab dengan cinta itu manusia ada dan tiada. Lebih jauh lagi ia mengatakan, cinta kepada manusia pada dasarnya adalah pengetahuan akan tidak adanya perbedaan di antara semua makhluk di hadapan Tuhan.

Di kalangan agama Hindu, cinta menjadi unsur terpenting. Dalam kitab suci Veda dinyatakan bahwa tubuh manusia adalah pura bangunan suci. Sedang jiwa (Sang Diri) adalah Tuhan Yang Maha Esa yang bersthana pada tubuh manusia. Dua kesadaran ini mengembangakan sikap prema-prema atau cinta kasih terhadap makluk hidup. Cinta itu adalah wujud kasih sayang. Dengan cinta kita hidup teratur antar sesama manusia, kita tak berkehendak saling memusuhi dan saling merusak apa yang ada di sekeliling kita. ${ }^{16}$

Berbeda cinta menurut agama Budha. Hal yang berkaitan dengan cinta mereka mengaitkannya dengan "Catur Pramita" atau Empat sifat ketuhanan. Ke empat itu di antaranya, cinta kasih, belas kasih, bahagia, dan keseimbangan batin. Dari keempat itu bila dilakukan manusia dalam kesehariannya akan mencapai kebahagiaan.

Sedangkan menurut Islam, cinta adalah menjadi nilai dasar keimanan dan kemanusiaan. Seperti dalam hadis, seseorang tidak akan dikatakan beriman sebelum ia mencintai orang lain seperti ia mencintai dirinya sendiri. Di kalangan Muslim sendiri, banyak sekali tokoh-tokoh yang memperjuangkan nilai-nilai cinta dalam beragama, terlebih pada kalangan sufi yang notabenenya bergelut pada dunia batiniah atau esoteris. Dari sini terlihat bahwa semua agama sangat memuliakan cinta dalam kehidupan.

Di dalam agama Islam istilah cinta sering disebut dengan mahabah. Kata mahabbah memiliki arti sebuah sikap kecenderungan yang melampaui batas minimal dalam ruang positif. Di dalam Islam pula cinta merupakan maqam ketuhanan. Allah membentuk karakter diri-Nya dengan nama al-Wadud (Maha
Mencintai). Dalam sebuah hadis, Dia disebut dengan sebutan al-Muhib (Pencinta). Itulah sebabnya Ibnu Arabi pernah mengatakan "ilmu adalah maqam paling mulia dan cinta adalah hal paling tinggi”.

Dalam keyakinan agama Islam pula, cinta menjadi penyebab keberadaan semesta. Dalam sebuah hadis pernah disebutkan, Aku adalah harta terpendam yang tidak dikenal, maka aku ingin dikenal, lalu Kuciptakanlah makhluk dan Aku memperkenalkan diri kepada mereka hingga mereka mengenal-Ku. Allah menyebut diri-Nya dengan "nafas ar-Rahman", ketika berbicara mahabbah, Dia mengajarkan kepada kita tentang realitas cinta dan cenderacenderanya sebagaimana sang pencinta menemukan cinta dalam dirinya. Oleh karena itu manusia yang tersinari oleh pancaran cinta Tuhan maka segala aktivitas kehidupannya pun juga memantulkan cinta seperti cinta Tuhan padanya.

\section{Cinta: Solusi Epistemologis Kerukunan Umat Beragama}

Puncak kebaikan itu adalah cinta. Artinya, kebaikan itu tak muncul atas dasar balasan dan tidak tenggelam atas cacian. Ia murni hadir dan bersimpuh menyapa setiap manusia, tanpa ada klasifikasi golongan maupun kelas-kelas sosial yang kita kenal belakangan ini. Ia bebas datang dan bebas untuk dimiliki siapapun.

Seseorang yang habis-habisan dihina dan dicaci maki tanpa ada riwayat kesalahan misalnya, tetapi kemudian ia membalasnya dengan sikap rendah hati, penuh keramahan bukan kemarahan, maka itulah cinta yang telah menjelma menjadi kebaikan. Sama juga, seseorang yang beragama kemudian bertemu dengan penganut agama lainnya dengan sikap saling menghargai, menyayangi, dan sebagainya pun termasuk cinta. Cinta sesama makhluk Allah. Contoh kedua inilah yang dialami langsung oleh Nabi Muhammad Saw. ketika beliau hidup berdampingan dengan Al-

\footnotetext{
${ }^{16}$ Frithjof Schuon, The Transendent Unity of Religions, (Quest Books, 1984)
} 
Muqauqis, seorang penguasa Mesir dengan nama lainnya Patriak Alexandria. ${ }^{17}$

Cinta telah menghapus atribut-atribut yang bersifat formalitas. Cinta tidak lagi memandang apa jabatan, apa agama manusia, apa status dan perannya. Yang diingat adalah, aku manusia, engkau manusia, kita semua adalah manusia. Maka ketika kita menyadari bahwa kita adalah manusia yang hidup secara akal dan hati, tugas kita adalah saling mencintai. Tidak ada lebih dari itu. Hal seperti inilah yang diharapkan untuk menjaga stabilitas kemanusiaan.

Meminjam istilah Thommas Hobbes dalam teori mekanisnya, manusia memiliki memiliki tujuan dasar. Tujuan dasar manusia adalah mementingkan dirinya sendiri. Dengan adanya tujuan dasar ini, ia tertuntut untuk mengakui hak-hak orang lain sebagai manusia yang sama-sama mementingkan diri sendiri. Dengan demikian, ketika manusia bertemu dengan manusia mereka harus membuat yang namanya kontrak sosial. Di situlah posisi cinta berada, membuat kontrak sosial itu. Di sini, menurut penulis, hobbes sangat mendukung perlunya kesolehan sosial.

Islam pun mengakui, dari sekian banyak surah dan ayat di dalam al-quran, kebanyakan di antaranya mendidik manusia mencapai puncak yang tak cukup soleh individu, tapi juga soleh secara sosial. Banyak contoh di dalam alquran yang bisa kita pahami sendiri. Maka, tidak berlebihan jika dikatakan bahwa orang yang hidup saleh secara sosial, adalah orang yang penuh cinta. Ia tidak hidup dengan kebekuan, melainkan Ia hidup bagaikan air yang mampu mengisi segala ruang karena sifat cairnya. Maksudnya ia mampu menerima dan hidup dalam perbedaan.

Dalam penelitian yang dilakukan Jalaluddin Rahmat terhadap alquran, ia mengatakan bahwa ada empat poin yang bertemakan tentang kepeduliannya terhadap masalah sosial. Pertama, pesan di dalam alquran serta kitab-kitab hadis, secara general proporsi terbesar ditujukan pada urusan sosial. Kedua,

\footnotetext{
${ }^{17}$ M. Quraish Shihab, Membumikan Al-Quran,

(Bandung: Mizan, 2013) edisi ke 2, cet I, Hlm. 339.
}

jika dalam ibadah bersamaan dengan urusan muamalah yang penting, maka ibadah boleh ditangguhkan terlebih dahulu (bukan ditinggalkan). Ketiga, bahwa ibadah yang mengandung nilai kemasyarakatan diberi reward lebih besar dari pada ibadah yang sifatnya persenal. Keempat, bila dalam perkara ibadah dilakukan tidak sempurna atau batal, karena melanggar aturan- aturan tertentu, maka cara menebusnya (kaffarat-nya) ialah melakukan sesuatu yang berhubungan dengan masalah sosial. ${ }^{18}$ Kecintaan dan ketaatan manusia pada syariat yang diyakini mesti berbuah pada kecintaan pada manusia.

\section{KESIMPULAN}

Cinta merupakan titik temu antara filsafat perennial dan tasawuf. Hal itu bisa dilihat dari kajian kedua diskursus ilmu ini yang memberikan perhatian khusus pada esoterisme agama.

Setiap agama mengakui keberadan cinta, daan bahkan mereka mengagungkannya. Di dalam agama Islam cinta sesama manusia menjadi tolak ukur keimanan seseorang, seperti yang ada dalam hadis Rasul, "tak seorang pun di antara kamu yang beriman sepanjang tidak mencintai saudaranya sebagaimana ia mencintai dirinya. Di dalam agama Kristen bentuk cinta itu terungkap dalam sebuah ungkapan: apa pun yang kau inginkan pada orang lain untuk dilakukan padamu, maka lakukanlah pada mereka. Sama halnya dengan Kristen, yahudi memiliki konsep cinta yang hampir sama: jangan lakukan pada orang lain apa yang kamu tidak ingin orang lain lakukan padamu. Dalam keyakinan Hindu, cinta dimaknai dengan: siapapun tidak boleh memperlakukan orang lain dengan cara yang tidak menyenangkan bagi mereka sendiri.

Dengan demikian, apa yang diyakini setiap agama tentang cinta dapat menjadi pijakan epistemologis kerukunan beragama.

\footnotetext{
18 Jalaluddin Rahmat, Islam Alternatif, (Bandung:
} Mizan, 1997) cet, IV, Hlm. 48-51. 
DAFTAR PUSATAKA

Abddurrahman, dkk. 2011. Al-Quran dan Isuisu Kontemporer. Yogyakarta: elSAQ Press.

Ali, Mukti. 1987. Beberapa Persoalan Agama Dewasa Ini. Jakarta: CV Rajawali.

Amstrong, Karen. 2013. Compassion: 12 Langkah Menuju Hidup Berbelas Kasih. Bandung: Mizan.

Anwar, Rosihon. 2010. Akhlak Tasawuf. Bandung: Pustaka Setia.

Bagir, Haidar. 2017. Islam Tuhan Islam Manusia: Agam dan Spiritualitas di Zaman Kacau. Bandung: Mizan

Betrand, Jacques. 2012. Nasionalisme dan Konflik Etnis di Indonesia. Yogyakarta: Ombak Dua.

Drajat, Zakiah. 1996. Perbandingan Agama 2. Jakarta: Bumi Aksara.

Espasito, John dkk. 2015. World Religions Today: Agama Agama Dunia Dewasa Ini. Jakarta: PT Elex Media Komputindo.

Ghurab, Mahmud. 2015. Semesta Cinta Ibnu Arabi. Yogyakarta: INDeS

Hdayat, Komaruddin. 2012. Agama Punya Seribu Nyawa. Jakarta: Noura Books.

Ismail, Faisal. 2016. Islam, Doktrin, dan Isuisu Kontemporer. Yogyakarta: IRCISoD.

Jr, Honing. 1988. Ilmu Agama. Jakarta: PT BPK Gunung Mulia.

Khalil, Hassan. 2016. Islam dan Keselamatan Pemeluk Agama Lain. Bandung: Mizan.

Kuswanjono, Arqom. 2006. Filsafat Perenial dan Rekonstruksi Pemahaman Keberagamaan. Yogyakarta: Filsafat UGM.

Nottingham, Elizabeth K. 1996. Agama dan Masyarakat. Jakarta: Rajawali Pers.

Rahman, Fazlur Dkk. 2000. Agama Untuk Manusia. Yogyakarta: Pustaka Pelajar.

Rahmat, Jalaluddin. 1997. Islam Alternatif. Bandung: Mizan.

Sabri, Mohammad. 1999. Keberagamaan Yang Saling Menyapa. Yogyakarta: ITTAQA Press.

Schuon, Fritchof. 1993. Islam dan Filsafat Perennial. Bandung: Mizan

Shihab, Quraish. 2013. Membumikan alQuran. Bandung: Mizan.
Sumartana, dkk. 1993. Dialog: Kritik dan Identitas Agama. Dian/Interfidei.

Umar, Nasarudin. 2015. Tasawuf Modern: Jalan Mengenal dan Mendekatkan Diri kepada Allah Swt. Jakarta: Republika. 